\title{
End of an Era: Transforming Language and Society in Japan, Korea, and Vietnam, c. $1870-1950$
}

\begin{abstract}
Scholars have generally taken a "diffusionist" view of the rise of national standard languages - the state pushes for the wider adoption of such languages, and other forces (principally economic modernization) facilitate its diffusion. But such a view is too mechanistic and Eurocentric, and an examination of other, less-familiar cases lends itself to a revised interpretation. Amid Western imperialism and the rise of nationalism in East Asia in the late I 9 th and early 2oth centuries, a massive shift in language practices took place between about I 870 and I 950, as regional hegemony shifted from China to Japan. Bound for two millennia by their common use of Classical Chinese, elite literati in China, Korea, Japan, and Vietnam all moved away from that abstruse lingua franca and turned to the creation of new national vernaculars. I argue for a more "integrationist" perspective: language nationalization was a state-led and top-down process directed at remaking society.
\end{abstract}

Keywords: Language; Nationalism; Japan; Korea; Vietnam; Diffusion

A M I D W E S T E R N I M P E R I A L I S M and the rise of nationalism in East Asia in the late I 9th and early 2oth centuries, perhaps the most significant change that occurred was the massive shift in language practices that took place between about i 870 and I 950, as regional hegemony shifted from China to Japan. Bound for two millennia by their common use of Classical Chinese, elite literati in China, Korea, Japan, and Vietnam all moved away from that abstruse lingua franca and turned to the creation of new national vernaculars. Today, each country has a distinct national standard language written in its own script, which in Japan consists of a combination of Chinese characters and kana; in Korea, a script with an indigenously developed alphabet; and in Vietnam, a Latin-alphabet script. Only China has retained Chinese characters as a written medium 
but, even then, for a very different language from that of the past. These new languages were meant to (and did eventually) inhabit an entirely new social environment. Before, literacy had been reserved for a small elite, and the difficulty of the language they monopolized-Classical Chinese-was seen as a feature and not a defect. When circumstances changed, however-with the industrializing nations of Europe and the US beginning to force trade and diplomacy on their own terms onto Asiathe resulting crises in each country forced a reevaluation of existing cultural practices and attitudes. Obscurity in language was no longer a virtue in a world in which mass literacy appeared intimately connected with national strength: the new national vernaculars had to be made accessible, both linguistically and institutionally. The new social word of these vernaculars included such institutional innovations as public education; a commercial publishing industry; musical recordings, radio, and films made for a mass market; a national industrial economy; and a global system of national states engaged in a Darwinian struggle for survival of the fittest. Amid these modern institutions and practices, an official language that required years of study and was accessible only to a small minority of the population no longer had a place.

What is modernity in the context of language? The answer to such a question depends on whether one treats modernity as a positive or a normative state-that is, whether one's conception of modernity is descriptive or prescriptive. Virtually no one treats modernity strictly as one or the other; most accounts discuss modernity from both perspectives. Nonetheless, each perspective remains distinct and is almost always in tension with the other. For instance, Bourdieu, in discussing language, takes modernity as a given-it is, after all, the principal concern of sociology-and describes contemporary language practices as a part of modern social reality. The "standard" or "official” language, for him, is the language consecrated by the state as the best kind of language, which forms part of the habitus of the best kind of people (who constitute the "dominant classes"). The arbitrariness of a standard language goes almost unnoticed, its superiority misrecognized as "natural." Thus, Bourdieu takes a more descriptive approach, while ascribing the prescriptive (normative) aspects of standard language ideology to the complicit misrecognition of the masses [Bourdieu I 99 I : 43-65]. In so doing, he echoes Gramsci, who posited that, whenever the "question of the language" arises, larger changes are taking place in the relationship between the "governing class" and the "national-popular mass"-in other words, a reorganization of cultural hegemony, in which the rulers strengthen their position and the masses are complicit in their own 
linguistic domination [Gramsci I 99 I : i 83]. Eugen Weber, on the other hand, takes a more even approach, describing the normative aspirations of French revolutionaries for linguistic uniformity (and thus national unity) coming into conflict with the stubbornly polyglot reality of France in the late $\mathrm{I} 8$ th and early $\mathrm{I} 9$ th centuries. From a modernization standpoint similar to that of Karl Deutsch [1966], Weber shows that it was only later in the I 9th century, when the larger social context in France changed-industrialization, urbanization, war mobilization-that revolutionary nationalist aspirations for linguistic uniformity were gradually attained. Thus, for Weber, the normative aspirations of nationalism preceded-and were facilitated by-the positive achievements of economic development. The spread of standard (Parisian) French was helped by the rise of an economic context in which provincial speakers of dialect (patois) found that speaking French was personally advantageous [Weber I 976: 67-94, 303-337].

\section{The diffusionist model}

For both scholars, the unit of analysis is the nation-state, which exists in a world of other nation-states. Thus, linguistic modernity is read as linguistic nationalization, in which all citizens supposedly have equal access to learning the national language. This putative equal access is what Bourdieu criticizes, given that the abstruseness of the standard language plays an important role in class reproduction. Linguistic modernity thus comes about through the diffusion of a standard language from a geographical and class center-the Parisian bourgeoisie, in the French case. The spread of this language is then facilitated by a variety of forces. In Weber's account of a modernizing France, these forces include industrialization and urbanization. For Benedict Anderson [I 99 I], who leans heavily on the Annales-school historians Lucien Febvre and HenriJean Martin [ 1 976], the main force is print-capitalism. While this diffusionist model at first glance seems plausible, its reliance on European examples limits its usefulness in helping us understand the process elsewhere. The usual interpretation of Europe's experience of vernacularization, in which Latin was gradually supplanted by national vernaculars that then in turn supplanted local dialects, takes a structuralist view of language. That is, a language is a self-contained symbolic system involuntarily inherited within a community whose boundaries are often defined by that language-whether based on class or ethnicity; it follows 
then, that a language is elite because elite people speak and write it. Thus, as Weber has it, "French" is the language of the Parisian bourgeoisie, and French becomes more widespread almost in spite of elite efforts to spread it through the schools. Rather, it diffuses beyond its social and geographic origins because, for an urbanizing population, it is the key to accessing employment and opportunity.

As we will see, however, the process of attaining linguistic modernity in East Asia was far more state-led and top-down, not least because the region's premodern language situation was more complicated than people unfamiliar with it might think. Moreover, modernity in Asia arose within a context of an imperialist world system that shaped developments in each country in different ways depending on their position within the system and their relations to different regimes at different times. Indeed, the diffusionist model's geographical and conceptual narrowness leads us to such errors as Anderson's, when he says that Japan, unlike the national states of Europe, was possessed of a "relatively high degree of... ethnocultural homogeneity"-it was not [Lie 200I]-and that its "halfSinified ideographic reading-system was long in place throughout the islands, and thus the development of mass literacy through schools and print was easy and uncontroversial" —a mistake, as I will show, based on a misunderstanding of the "reading" (writing?) system [Anderson I99 I: 95-96].

\section{The integrationist model}

In the course of the 19 th and 2oth centuries, the countries of Asia that had previously shared in their use of Chinese characters and Classical Chinese each engaged in contentious debates about language standardization, and each developed national linguistic forms to suit the context of modern national societies. The developments in each country influenced those in neighboring countries, and all were influenced by what they perceived to be Western language ideologies and models of practices and institutions. I focus on Korea, Japan, and Vietnam in this essay because, until the end of the I 9 th century, they were bound to China by an elite culture for the better part of two thousand years. More importantly, each country's modern history after the collapse of Chinese hegemony was marked to varying degrees by a nationalist rejection of the Chinese heritage. I show that, while the selection of Europe's national vernaculars might have been relatively "unselfconscious" early-modern bureaucratic 
developments-only afterwards to be taken up by dynasts in pursuit of "official nationalisms" [Anderson I99I: 42, 84]-Asian nationalisms, which arose later than their European counterparts, took European developments as a model, but implemented them much more aggressively. The selection and codification of national standard languages by newly constituted nation- and empire-states in Asia was eminently selfconscious, and both the design and spread of these languages were marked by efforts to be more egalitarian than before- the languages were purposely made simpler for greater ease of access, thus facilitating a nationalist project of "status integration" as well as "cultural integration" [Lie 2004: 99].

I argue that the Asian cases I examine, different as they are from the European norm, are better understood through an integrationist model, in which linguistic unification is pursued far more inclusively and heavyhandedly by the state. Rather than explaining today's dominance of national standard languages as resulting from diffusion from a class and geographical center (the bourgeois elite of the capital city), I show that, in my Asian cases, social elites arbitrarily designated the educated speech of the capital cities as the basis of the national standard language. While European standard languages were in many ways "artificial" [Weber I 976: 336], their Asian equivalents were even more extreme in their artificiality, having virtually no constituent speakers or writers before their creation. The propagation of these languages therefore was necessarily much more top-down: a language cannot diffuse from a center if it has no initial population of speakers. In each case, the standard language was based on, but not identical to, the existing speech of the capital. The new standard language had first to be taught to teachers before being spread among the people. New media had to be created from scratchvernacular newspapers, school textbooks, radio, film, phonographs-and all had to be cultivated and monitored for linguistic conformity. In each case the heavy hand of the state was the guiding force. Japan, Korea, and Vietnam, in short, represent extreme versions of what their elites perceived to be the European norm when it came to state language policy.

In the following sections, I first outline the premodern language situation in Asia. The discussion then proceeds chronologically, starting with Japan, followed by Korea and then Vietnam: in each case, I demonstrate how an integrationist model better accounts for the rise of the national standard language than the regnant diffusionist model. Furthermore, the implications of my alternative perspective for social theory are manifold. The diffusionists' explanation of the past is often used to criticize the conditions of the present: the diffusion of a standard language 
represents a "colonization" of the periphery by the center [Weber I 976 : 485-496]. Bourdieu's approach is similar-the standard language aids the reproduction of privilege. My integrationist model delivers a different perspective: while there will always be advantaged and disadvantaged people under any set of social arrangements, the Asian cases show that the very incorporation of previously excluded populations into a unified language and educational system represents an advance, however flawed, toward a more egalitarian vision of society.

\section{Premodern East Asian cosmopolitanism}

For the Anglophone readership of this essay, it might be difficult to imagine a world in which the upper classes used a language wholly different from the rest of the society, but much of East Asia (and Europe) inhabited just such a world up until the I 8 th and I 9 th centuries. In China's East Asian neighbors-Korea, Japan, and Vietnam-the language of government, scholarship and religion was Classical Chinese. ${ }^{\mathrm{I}}$ The power and appeal of what we think of today as foreign languages was very much a part of elite life in premodern Europe and Asia. In Europe, Latin was integral to governmental and intellectual life in the medieval and early modern periods, and French was the dominant language of aristocrats and the educated bourgeoisie in the $\mathrm{I} 7 \mathrm{th}$ and $\mathrm{I} 8$ th centuries [Leonhardt 20 I 3: I-8, 36; Gordin 20 I 5: i 6-i 8]. The strangeness to us of people in the thrall of what we would consider to be foreign languages speaks to how thoroughly the ideology of nationalism has permeated the contemporary consciousness. Nationalism calls for political communities bound by a common culture, of which language forms a critical component. The idea that the elite members of a polity would have more linguistically in common with elites from other countries than with other members of their own seems quite unnatural to us [Lie 2004: I 3-2 I]. But such was the case in East Asia right up until the end of the I 9 th century.

\footnotetext{
I Instead of the term "Classical Chinese," distinguished linguist and sinologist Victor Mair [Kornicki 20I8: I 9; Mair I994: 708, 2004: II; Wells 20II: I] prefers his own coinage "Literary Sinitic" for its precision, since the term indicates the language's status as but one member of the larger SinoTibetan family of languages. In advocating such a nomenclature, however, he has largely
}

remained vox clamantis in deserto [Mair 2004: I I]. I persist in using the term "Classical Chinese" for the convenience of its greater popular familiarity, and also because, as I argue in this essay, much of the emergence of linguistic modernity in China's East Asian neighbors consisted in the nationalist rejection of the Chinese heritage. 
Literate elites in Korea, Japan, and Vietnam were thoroughly imbued with the Confucian canon and with the language in which it was written: Classical Chinese. It is difficult to imagine a Western analogue to the complete and utter dominance of this form of culture among the upper echelons of society. Latin is frequently cited as a comparative case, but Latin was a language that originated in a polity, Rome, that had long since passed into history by the time of its ascendance throughout Europe in the Middle Ages and the early modern era. Indeed, it is important to note that the great majority of Latin texts were written after the fall of the empire [Leonhardt 20I3: I 4]. In essence, Latin was a language whose original speech community had long since disappeared but was kept alive by the literate elite of multiple lands. In contrast, the society in which Classical Chinese originated, in spite of invasions, conquests, and periodic dynastic changes, had never ceased to exist, and it constituted the region's political and economic center of gravity until the mid-I9th century. Its cultural hegemony was such that, while many books produced in China were sought after and obtained outside of China, very few books-even those written in Classical Chinese-ever made their way in the reverse direction. Peter Kornicki has described Chinese textual culture before the I 9 th century as "self-sufficient"; the productions of writers outside of China were largely beneath the notice of the Chinese literati. Buddhism, one of Asia's major transnational religions, was transmitted to Japan, Korea, and Vietnam virtually exclusively through Chinese translations; Buddhist and Confucian texts, philosophical and political treatises, works on military strategy, and dynastic histories were among the books written and published in China that were in high demand in Japan, Korea and Vietnam. Scholars, bureaucrats, and diplomats from these neighboring countries regularly traveled to China specially to obtain these texts. Scholars outside of China needed to go to China and have their books published there in order to gain any wider notice-a situation quite unlike that in Europe, where books routinely circulated among different countries [Kornicki 2008: I7-2I, 2018: I $30-$ I 54].

Given the utter dominance of Chinese culture and Chinese language for the better part of a thousand years, the reorientation of East Asia in the I 9 th century from a Sinocentric regional order to a Eurocentric global system was bound to be painful and traumatic. The prestige of China's culture had been rooted in its great size, wealth, and military power relative to its immediate neighbors. In the millennium prior to 939 CE, most of today's northern Vietnam had experienced direct Chinese rule, and the area faced repeated invasions during the Ming 
(I368-i 644) and Qing ( I644-I9 I I) dynasties. Korea had sustained repeated invasions from China, most notably in the early I6oos in the chaotic years before the start of the Qing dynasty, when Manchu invaders forced the country's Chosŏn ( I 392-I 9 IO) rulers to break their allegiance to the defeated Ming dynasty. And Japan, though it did not face a direct military threat from China, having remained largely isolated through much of the Edo period ( I603-I 867) under its Tokugawa rulers, nonetheless remained in the cultural thrall of Chinese language and texts until the middle of the I 9 th century [Dreyer 20I6].

By the r 920 s and I930s, in contrast, all of the modern nations that formerly had used Classical Chinese as a prestigious medium of communication had marginalized that linguistic heritage and adopted homogenizing national language policies. Local vernaculars in Japan, Korea, and Vietnam were standardized and elevated to official, national status. Gone were the class and status distinctions that had divided each country's populace on the basis of language competency. In place of the diglossia of Classical Chinese and multiple local vernaculars that had marked the elite language practices of each country for more than a thousand years, unification proceeded instead among all classes within each country's national borders: all citizens of these newly reimagined national communities were obliged by the state, through newly created modern mass education systems, to learn the national language, based on the educated speech of each country's capital. In surveying the course of language reform among the countries in East Asia that formerly used Classical Chinese as a medium of elite communication, it becomes clear that Japan was at the forefront of this trend; it was the earliest country to embark on a program of modernization, which uniquely it was able to do largely on its own terms, especially by the end of the I 9 th century.

\section{Fapan}

In many ways, the massive shift in social practices in East Asiaindustrialization, the opening up to global trade, military modernization, nation-building-began in Japan. That Japan was at the vanguard of this kind of change is startling in one respect because, from the perspective of the Western powers at the time-Britain, France, the United StatesJapan was rather marginal in the broader scheme of Far Eastern trade. China was by far the larger market, and China's centrality and importance to global commerce is in part why the British, the foremost 
exponents of free trade, concentrated on their access to the China trade to the point of instigating war in I 839. The First Opium War with China ( $1839-1842$ ), in which Britain forcibly expanded its access to Chinese ports, stemmed from a breathtaking sense of commercial entitlement rooted in a peculiar marriage of politics and economics first expounded in the I 8th-century political economic theory of the Scottish Enlightenment [Hont 2005: I -8]. The greed of individual traders and adventurers intersected in the first third of the i 9 th century with the newfound conviction of an increasing number of politicians that economic interests were inseparable from national interests [Platt 20 I 2: 26 I-62; Semmel I 970: 7-I3]. In fact, unbeknownst to the Japanese, as early as I 845 the British were planning to open Japan, by force if necessary, but they found themselves tied down in the Crimean War ( $1853-1856$ ) along with two other potential rivals in Asia, the French and the Russians [Green 20 I 7 : 49]. Thus, the United States, whose recently acquired Pacific coast territories of California and Oregon reinforced its interests in the Pacific, sought to negotiate access to a coaling station and Japanese ports by sending a naval squadron led by Commodore Matthew C. Perry ( I 794-I 858), who arrived in Edo Bay in July I 853 .

Given Western modernity's intrusion into East Asia in the I 9 th century, numerous debates went on in elite circles in Japan about what had enabled Western superiority and what Western practices were worth imitating. Up until the end of the I 9 th century, Japan's language situation was highly stratified, with considerable linguistic diversity scattered across the country among the uneducated masses, and a variety of registers of speech and writing used among the tiny educated elite. Such a hierarchically segmented language situation made sense in the feudal society of the Tokugawa Shogunate (i 600-I 868). However, with the imposition of a unified and increasingly powerful central government under the imperial partisans that came to power during the Meiji Restoration in $\mathrm{r} 868$, such a situation seemed more and more out of touch with the society that they thought Japan needed to become in order to retain its independence from increasing Western encroachment. Thus began a decades-long cultural engagement with outside societies characterized by an intensity hitherto unseen. Missions from Japan were sent to Europe and the United States, and one of the best remembered exchanges of this period was that between Mori Arinori ( I 847-I 889) and William Dwight Whitney ( I 827-I 894). Mori, a prominent statesman, diplomat, and a founder of Japan's modern mass education system, published in I 873 a book of letters that he had solicited from American educators. The 
best-known exchange from this collection was with Whitney, a linguist at Yale famous for his philological research in Sanskrit. In their exchange, Mori inquired if the language situation in Japan was irreconcilable with the modern world, and whether as a result the Japanese should learn English instead. Whitney suggested that, in Japan, English should replace Classical Chinese as the language of scholarship and government, while retaining Japanese as the everyday language of communication [Whitney I 873]. This exchange has subsequently been remembered as an instance in which Mori sought the replacement of Japanese with English, though such a reading is an exaggeration [Lee I 996: 7-I 4].

Nonetheless, this episode was a sign of the freewheeling nature of debates over language reform in Japan in the late I 9 th century. Under the new imperial regime, many more things seemed possible than ever before, and the complexity of existing language practices meant that there were many options for reform. In addition to Classical Chinese at the apex of linguistic prestige, the Japanese had developed several different vernacular styles of writing atop a striking diversity of spoken languages across the different classes and regions of the country. Intellectuals interested in the development of a Japanese nation and the reform of language practices to further that goal formed many different organizations. Prominent among these organizations in historical memory were the Meiji Six Society, the Kana Society and the Rōmaji Society. The Meiji Six Society, or Meirokusha in Japanese, was so named for its founding in I874, the sixth year of the Meiji reign (I868-I 9 I2), and it counted among its members such eminences as Mori Arinori and Fukuzawa Yukichi (I835-I90I). Fukuzawa was a prominent author and teacher, as well as founder of the prestigious Keiō University. He and the other members of the Meirokusha, though not always in agreement about particulars, sought the standardization of the Japanese language [Clark 2009: 27].

The proliferation of societies interested in such language reform pointed to the many options for standardization from which reformers could choose. The members of the Meirokusha sought a simpler written style. The Kana Society, whose name reflected its advocacy of the hiragana and katakana syllabaries indigenously developed in Japan in the 9 th century, was founded in I 884 as a merger of two related language reform groups. The Rōmaji Society was founded in the same year and, as evidenced by its name, advocated the Romanization of Japanese writing. Both groups sought an end to the use of Chinese characters in Japanese writing altogether. Nor was orthography the only issue at stake in language reform. The prevalence of any given written style in late 
I 9th-century Japan fluctuated greatly, and there were several to choose from. Kanbun, or Classical Chinese as used in Japan, was written wholly in Chinese characters. Sórōbun, an epistolary style less formal than kanbun named for the predominance of the copula $s \bar{o} r \bar{o}$, was derived from a modified form of kanbun, written in a combination of Chinese characters and kana in early Meiji times. Wabun, or Classical Japanese, was derived from colloquial writing entirely in kana in the Heian period (794-I I 85). And wakankonkōbun was a literary Japanese style with, as its name suggests, kanbun elements mixed with Japanese colloquialisms, frequently used in government documents in the Meiji era [Clark 2009: I 4-22; Twine I 99 I: 48].

None of these difficult written styles reflected the speech of anyone in early Meiji Japan. With Japanese missions returning from Europe and the United States, the beginnings of a nationalist language ideology began to take shape, most prominently with the byword genbun itchi, or the "congruence of speech and writing." Colloquial writing and advocacy for language reform had appeared even before the Meiji Restoration. Religious tracts dating to the $\mathrm{I} 8 \mathrm{I}$ os recorded sermons verbatim, and the first official call for a reform of writing came in I 866: Maejima Hisoka ( I 835-I 9 I 9), Japan's first postmaster general, petitioned the shogun for an end to the use of kanji (Chinese characters) and a simplification of the language used in textbooks, an idea that at the time fell on deaf ears. Nevertheless, a series of institutional developments in Japanese society increased the need for a language for the masses: the founding of the first daily newspaper in I 870 (followed by many others), the formation of a Ministry of Education and the postal system in $\mathrm{I} 87 \mathrm{I}$, and the inception of compulsory education in 1872 . Intellectuals in newspapers began publishing opinion pieces discussing the merits of a writing style that more closely reflected everyday speech [Twine I 978: 337-342].

The primacy of speech in linguistic thinking was inherited from late I 9 th-century European linguistic trends, which were heavily influenced by a group of German language scholars known as the Neogrammarians (Funggrammatiker). This group of scholars was known for its advocacy of the idea that changes over time in the sounds of a language proceed according to "rules without exceptions" [Amsterdamska I 987: 94; Lee I 996: 79; Weinreich, Labov, and Herzog i 968: i I 9-I 20]. German linguistics in general at the time was perhaps the most well-developed and thoroughly institutionalized in the Western world, and its influence was felt in Japan through the work of Ueda Kazutoshi (I 867-I 937), one of the biggest names in the formation of a nationalist Japanese language policy. Ueda was an i 888 graduate of the Department of Classical 
Japanese Literature at Tokyo Imperial University and was a student of Basil Hall Chamberlain's ( I 850-I 935). Chamberlain was a professor of linguistics at Tokyo Imperial University, a supporter of genbun itchi and a founding member of the Rōmaji Society [Clark 2009: 84- I o6; Lee I 996 : 73-89].

The primacy of speech in the thinking of language scholars and language reformers stemmed from the Neogrammarian tendency toward phonocentrism, the idea that sound is more fundamental to language than script. This attitude went against assumptions that had prevailed in Asia for the better part of two thousand years: an emphasis on the primacy of Classical Chinese script, which could be rendered into sounds in many different ways depending on local speech customs, much like mathematical notation read aloud in different languages. That is, any given text written in Classical Chinese could be read aloud in a multitude of ways: the Japanese would do so according to their pronunciations (or "readings"), the Koreans according to theirs, and the Vietnamese according to theirs; not to mention the many different kinds of regional pronunciations to be found in China. All of these different readings would not necessarily have been mutually intelligible to one another, despite the same underlying written language they were meant to reflect [Kornicki 20 I 8: I 7-I 8].

The reversal in linguistic priorities, then, resulted from European influence. This trend, motivated by foreign ideas, waxed and waned in the next three decades, and the existing historiography recognizes two phases. The initial phase of the rise of genbun itchi occurred in the periodical press and schools in the i 870 os and I880s, while the latter phase occurred primarily in literature starting in the 188 os through the I 9 I os [Heinrich 2005: I I 6; Twine I 978: 339]. The urge to reach more readers motivated the publication of colloquial articles in periodicals in the I 870 s, many of whose text was mainly kanbun, although the number of colloquial articles began to decline in 1879 , possibly because of a perceived increase in their readership's educational levels [Twine I 99I: 95]. Conservative and xenophobic opposition incited the next retrenchment in the late $\mathrm{I} 88 \mathrm{os}$, following a general political swing to the right, and acrimonious debates over genbun itchi appeared in a series of exchanges in the pro-colloquialization magazine Bun ("The Written Word" or "Letters") and in the Tokyo newspaper Yomiuri Shimbun that began in late I 888 and lasted into the summer of I 889 . The intellectuals who opposed a general colloquial writing style generally objected to what they saw as its coarseness. While the debate ended inconclusively in I 889, developments in Japanese literature continued in parallel. The 
year I 875 saw the publication of the first major vernacular Japanese novel, Ukigumo (The Drifting Cloud) by Futabatei Shimei (I 864I 909), who was followed by several other authors. A temporary retrenchment in the conservative years of the early i 890 s gave way to a burst of national self-confidence after victory in the First Sino-Japanese War (I894-I 895), which resulted in the decline of the prestige of Chinese linguistic influences in the older forms of Japanese writing. By I 908, all novels published were in the colloquial. Schools began dropping older forms of writing in favor of genbun itchi, and newspapers altogether ceased printing in older styles by 1926 [Heinrich 2005: I 29-30; Twine I 99 I : I 98-204].

A leading figure in the state's codification of modern Japanese was Ueda Kazutoshi, who had studied in Germany on government scholarships, starting in $\mathrm{I} 890$ at Berlin University and then in $\mathrm{I} 892$ at Leipzig, where he worked with the prominent Neogrammarians August Leskien ( I 840- I 9 I 6), Karl Brugmann ( I 849- I 9 I 9), and Eduard Sievers ( I 850I 932). During his time in Germany, Ueda adopted the German Romantic view that a given language was the embodiment of its society-a nation [Kaske 2008: 24-25; Lee I 996: I I 8-I 30]. When in I 894 he returned to Japan and was appointed Professor of Linguistics at Tokyo Imperial University, he became thoroughly instrumental in the formation of a national language policy. In I903, Ueda, Maejima Hisoka and other "prominent educators, linguists, authors, and journalists" helped found the National Language Research Council (Kokugo I'inkai), which was established by a legislative act of the Imperial Diet to standardize the Japanese language [Clark 2009: I 24]. The national language that ultimately emerged from the Council's codification efforts was called kokugo. This term represented a lexical "round trip" from China: the two Chinese characters used to write the word kokugo originally meant "language of a country" or "language of a place" but, as neologized by the Japanese (under German Romantic and nationalist influence), it came to mean "language of a nation." Later in this essay we will see kokugo reappear first

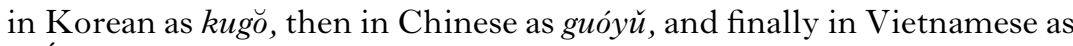

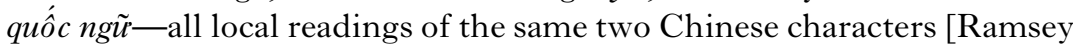
I 99 I : 37,44]. Arguments over what this kokugo should look and sound like had raged in Japan over the three decades following the Meiji Restoration in I 868, and the spoken form it achieved towards the end of the Meiji era was essentially the upper-class Tokyo dialect, shorn of localisms, with the incorporation of some token Kyoto dialectal elements, while its written form consisted of a mixture of Chinese characters and 
the katakana syllabary [Clark 2009; Heinrich 20 I 2; Kaske 2006; Twine I 99 I].

The standardization and nationalization of the Japanese language, contrary to Anderson's [1991: 96] account, was thus far from simple. Nevertheless, over the last three decades of the I 9 th century, Japan set the linguistic agenda for the rest of East Asia. Influenced by its forcible opening to the West, it embarked on a quest to answer the questions it felt were raised by the cultural and institutional changes concomitant with modernity: What was the relationship between the sound and script of a language? What was the relationship between a nation's language and its people? Japan's answers were distinct: the script of a language should closely follow its sound, and all of a nation's people were obliged to learn the national language through the new institution of mass education. While diffusionist thinking would posit the spread of a previously prestigious form of speech and writing from center to periphery, the Japanese case-in which the imperial capital itself was shifted from Kyoto to Tokyo-shows us that the process there was much more intentionally driven from the top-down. A new language ideology was adopted, a new language was invented, a new capital was designated, and a population newly conceived of as national was the target of these new ways of thinking. Japan's integrationist approach was to have a strong impact on its Asian neighbors.

\section{Korea}

The governing regime in Meiji Japan, in adopting the strategies of its Western adversaries to strengthen the nation, did not limit its reforms to domestic policy. Towards societies overseas, the government began behaving in ways that were rather similar to the Western powers that had so recently imposed themselves on Japan. It is in this context that an isolationist Korea enters the picture in $\mathrm{I} 875 \mathrm{with}$ a diplomatic incident in Kanghwa Bay, on the country's west coast, near Seoul. In that year, Japan sent three gunboats to Korea in an effort to open up diplomatic relations. When one of them was fired on, the Japanese saw fit to retaliate by returning fire on several coastal batteries. Subsequently, in January I 876, the Japanese sent three more gunboats to Kanghwa Bay with a diplomat charged with negotiating treaty relations with the Chosŏn government. The resulting Treaty of Kanghwa opened three Korean ports to trade with Japan and, moreover, stipulated that Korea was an 
“independent nation," meaning that its erstwhile tributary relationship with the Qing court in China was to be curtailed. While Japan's ambitions on the Korean peninsula were not to be substantially realized until its victory in the First Sino-Japanese War, the Kanghwa incident marked the beginning of Japan's engagement in "gunboat diplomacy," which heretofore had been confined to Western foreign policy. In a striking echo of Japan's forcible opening to trade by Commodore Perry's US mission in I 853, Japan had turned Western tactics to its own advantage. The shock of the opening of Korea precipitated major changes in the Korean state and society, not least language reform, which began in earnest in the years between the Treaty of Kanghwa and Japan's formal annexation of the Korean peninsula in I 9 I o [Iriye I 989: 745-746; Schmid 2002: 26].

For centuries, Korean linguistic culture had been thoroughly permeated by the Confucian canon and the Classical Chinese in which it was written. While its contemporary orthography consists almost solely of an alphabetic script, han'gŭl, the dominant language of Korean scholarship and government was Classical Chinese until the end of the I 9 th century. The alphabet itself had been developed in the early I440s under the direction of King Sejong (I397-I 450, r. I 4 I 8-I 450), the fourth monarch of the Chosŏn dynasty ( I 392- I 9 I O). Confucian scholar-bureaucrats in the government, in reaction to the development of han'gŭl, sought to double down on Classical Chinese's supremacy in Korean practice, now calling it chinsŏ and chinmun, "true writing" or "true script." Texts

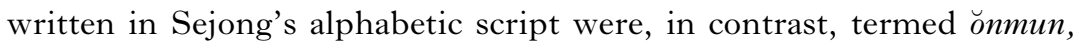
or "vulgar writing." Such a response seems an overreaction, especially given that han'gŭl was developed primarily to aid in the correct pronunciation of Chinese characters. It was, after all, promulgated in a 1446 publication entitled "The Correct Sounds for the Instruction of the People” (Hunmin Chŏnŭm). Moreover, the use of the term chinsŏ for Classical Chinese never acquired currency in China, Japan, or Vietnam. While a vernacular literature written in han'gŭl did arise after its creation, the importance of Classical Chinese, written in characters, remained undiminished until the end of the I 9 th century, given its central role as the written medium of the Confucian canon on which the civil examination system, modeled on that of China, was based. It was only after the Classical Chinese was marginalized in subsequent decades that han'gŭl became prominent as an element of non-Chinese indigeneity that nationalist language ideologists could draw on [Schmid 2002: 65-66; Wells 20I I : I 7-I 8].

Within months of the conclusion of the Kanghwa treaty in January I 876 , Korean state delegations began to be sent abroad on observation 
missions. The first of these missions were particularly struck by the new system of mass education that had begun to be developed in Japan, where commoners as well as elites-and even girls-were educated in schools using a curriculum that no longer gave primacy to Classical Chinese or its attendant canon. In part, as a result of this and subsequent missions, the importance ascribed to chinsŏ began to wane, and this decline in importance was evident in the increasing use of the word hanmun-the Korean equivalent of the Japanese term kanbun - to refer to Classical Chinese. Additionally, Korean-language writing began to be called kungmun, or "national writing," the spoken correlate of which was kugo - the Korean equivalent of the Japanese kokugo, "national language." Peter Wells [20II: 8-II] has argued that this terminological shift constituted a "decentering" of Classical Chinese within Korean discourse about language; indeed, Andre Schmid has described the discursive construction of a Korean national identity as a "decentering" of China in general [Schmid 2002: 55]. In the immediate decades after Kanghwa and under Japanese influence, ónmun ilch' $i$ - the Korean equivalent of the Japanese phrase genbun itchi-became an increasingly widespread catchphrase among literate elites who advocated language reform. Thus, as Korea's position within the regional political order took a turn for the worse, its language practices came under scrutiny.

In this context, the prevailing written style in Korea began moving away from the strict use of Classical Chinese in the i 880 s and I 890 os toward a mixed style known as kukhanmun, in which Chinese words still predominated, but were now interspersed with Korean particles written in han'gŭl. The shift did not occur without opposition, but the discourse of nationalism had become so widespread that traditional literati, whose education had been deeply invested in Classical Chinese, were reduced to arguing on nationalist grounds that Chinese characters were not foreign interlopers but in fact native to Korea [Schmid 2002: 69-70]. At the same time, Korean students began studying abroad in Japan. Two of these students, Yun Ch'iho (i 864-I 945) and Yu Kilchun (I 856-I 9 I 4), later became advocates of language reform. Yu was able to study at Keiō Gijuku, the early incarnation of today's Keiō University, under the school's founder Fukuzawa Yukichi, whom we met earlier as a language reformer and member of the Meirokusha. These and other students would subsequently bring back to Korea the German Romantic idea of indigenous speech as the essence of nationhood.

A string of unequal treaties, starting with the United States in I 882, followed by Germany (I 883), the United Kingdom (I883), Russia (i 884), and France (i 886), compelled the Chosŏn government further 
to open the country's ports to trade. The treaty with France specifically guaranteed religious freedom and the right to proselytize, which allowed Protestant and Catholic missionaries to enter Korea. These missionaries conducted their work through a number of channels, one of which was to run schools in which Classical Chinese was marginalized as one of multiple subjects that were taught. Additionally, missionaries began the task of translating the Bible into Korean, and their efforts to reach a broader audience meant that they pursued this task through the medium of kungmun, written in han'gŭl. As in other parts of East Asia, Western missionaries were baffled by the language situation in Korea. To better evangelize, Christian missionaries from the West were among the first to create dictionaries of Korean-in fact, such bilingual dictionaries predated by several decades the publication of the first monolingual Korean dictionary in 1938 . Given the unstandardized state of the Korean language situation, lexicography was no straightforward task. In addition to their efforts at translation, the missionaries also brought with them their attitudes regarding linguistic practice. To them, the sway that Classical Chinese held over Korean literary culture was off-putting, since it seemed increasingly obsolete to be in the thrall of a foreign culture in age of rising nationalism-a viewpoint of which the Koreans themselves were aware [King 2004: I5; Kornicki 2018: 47-48; Pieper 2017: IO I, I 54, 292, 299].

China's defeat in I 895 in the First Sino-Japanese War sharply marked the decline of Chinese political influence and cultural prestige in Korean society and the ascendance of Japanese power on the Korean peninsula. Earlier, in March I 894, a peasant rebellion had broken out in the southwestern province of Cholla, the proximate cause of which was the depredations of an unscrupulous official. The Tonghak rebels, so named for their guiding religious ideology ("Eastern Learning”), were quickly able to seize control of a significant portion of territory, including the provincial capital, Chŏnju. When government troops proved unable to retake the capital in June I 894, the Chosŏn court, fearful of the collapse of its authority, petitioned the Qing government for assistance in quelling the rebellion. The Qing agreed to send help, prompting the Japanese, who had been monitoring the situation closely, to send troops of their own. Though the Kanghwa treaty two decades before had stipulated the end of Korea's tributary relationship with the Qing court, in practice the relationship had never ended, and the Japanese seized the opportunity to realize their political ambitions on the peninsula. Japan, ignoring the state of truce between the Chosŏn government and the rebels, suppressed the Tonghak rebellion. By July i 894, the Japanese had taken control of 
the royal palace in the capital Hansŏng (now Seoul) and "sequestered" the monarch, provoking the Qing to go to war. Japan's victory over China in the ensuing first Sino-Japanese War in I 895, which surprised virtually all observers, precipitated a series of political reforms on the peninsula under Japanese direction. Korea was firmly excised from the Qing sphere of influence, but the "sovereignty" it gained under the terms of the Treaty of Shimonoseki that concluded the hostilities, attained by the force of Japanese arms, proved to be hollow and short-lived [Schmid 2002: 25-27].

Newly empowered in Korea, the Japanese from i 894 to I 896 were behind a series of political changes known as the Kabo Reforms, named for the lunar year in the sexagenary cycle of the Chinese calendar that fell mostly in I 895. The reforms covered many spheres of life-among them government organization, financial management, marriage practices, and the abolition of slavery-and language policy did not escape these changes. In a symbolic move, the government issued a statute in I 894 that elevated kungmun to the status of national script. The reforms abolished the traditional form of the civil service examination in 1894 , more than ten years ahead of its abolition in China in 1905 . For centuries, the system had tested candidates' knowledge of the Confucian canon, as well as their compositional ability in Classical Chinese. The cachet of Classical Chinese had always been rooted in its being a requirement for prestigious bureaucratic posts. The abolition of Korea's civil examination system struck a major blow to Classical Chinese's position in Korean society [Pieper 20 I I: 42; Schmid 2002: 62; Wells 20 I I: 6, 50].

Two major linguistic developments stand out in the years between China's defeat in I 895 and the Japanese annexation in I 9 I 0 : the rise and growth of a periodical press, and the development of mass education. This era, commonly known in the historiography as the "Enlightenment" period, was heavily colored by the catchphrase munmyong kaehwa, or "civilization and enlightenment," which was probably derived from the Japanese equivalent, bunmei kaika, a catchphrase popular in Japan in the I 870s and I 880s [Clark 2009: I 2; Schmid 2002: 24]. In 1895 , there were no "privately managed Korean-language newspapers" in Korea; twelve years later, there were several newspapers and "a dozen educational magazines" in circulation domestically and overseas [Schmid 2002: 47]. While the bulk of these publications were written in the kukhanmun mixed-script style, a few pioneers wrote solely using the alphabetical kungmun, most notably the Tongnip Sinmun (The Independent), founded by Korean American returnee Philip Jaisohn (Sŏ Chaep'il) (I864-I95 I) and Christian essayist Yun Ch'iho (whom we 
met earlier as a student in Japan), which combined radical politics with a staunch Christian outlook. Similarly, as modern education-public, private, and missionary primary and secondary schools — that taught a variety of subjects began to supplant traditional Confucian education, a new generation of people were raised on kukhanmun textbooks produced by the government, a striking departure from previous practice where Classical Chinese was the sole formal way of writing [Pieper 20 I 7: 107-20].

These developments - the opening of the ports, the decline of the prestige of China and its language and culture, and the rise of a modern press and language practices-parallel the developments underway in both of Korea's neighboring empires, China and Japan. Where Korean history diverges, however, is the increasing encroachment of Japan on its domestic affairs in the late 19 th and early 20 th centuries that culminated in a total takeover in I 9 I 0 . While Japanese officials had begun to play a role in Korean governance following the conclusion of the First SinoJapanese War in I 895, Japan's involvement escalated during its war with Russia (I 904-I 905). In spite of the Korean court's declaration of neutrality amid the conflict, the Japanese took advantage of the exigencies of war to strengthen their military and political position on the peninsula, and a Japanese minister took responsibility for education policy. In August I 905, the Japanese forced the Korean emperor Kojong, under military duress, to sign the Ülsa treaty making Korea a protectorate. In the midst of this high drama, the Chosonn government created the National Script Research Center in 1907, which collected a group of language scholars that included the founder of Korean linguistics, Chu Sigyŏng (I 876-I 9I4). When Kojong proved recalcitrant after the protectorate treaty, the Japanese forced his abdication in 1907 in favor of his apparently more pliable son, Sunjong, under whom, three years later in I 9I0, Korea was formally annexed to Japan [Schmid 2002: 28].

The annexation effectively cut off most of the indigenous developments in the evolution of Korean language practices for almost a decade. The Korean press was taken over by the Japanese colonial government and greatly diminished, and Korean as a language began to be taught in schools merely as one subject, the medium of education increasingly being Japanese. The oppressive political environment of the first decade of Japanese rule led to widespread discontent that found expression in I9I9 in the March First Movement, in which mass demonstrations prompted the colonial government to reconsider the terms of its rule, eventually loosening restrictions on expression. The vernacular press experienced a revival and growth in the I 920s, surpassing the previous generation of newspapers, each of whose circulation had never exceeded a 
few thousand. Korean language reform also continued. In I 92 I, students of Chu Sigyŏng founded the Korean Language Research Society (Chosŏnŏ Yŏnguhoe), forerunner to today's Han'gŭl Society, which promoted the term han'gŭl for Korea's alphabet that Chu himself had coined in I 9 I O. The Society also published a standardized orthography in I 933, though the colonial government itself had produced standardized Korean orthographies for use in schools through the I 9 Ios and I 920 s. The relatively tolerant state of affairs in language policy ended in I 938, as Japan's war of expansion in Asia intensified: the Korean language was further demoted, first becoming an optional subject, and then in 1942 being totally removed from school curricula [King 2007: 207; Pieper 20 I I: 68-88, 20 I 7: 400; Schmid 2002: 257].

It was only after Japan's defeat in 1945 that Koreans regained control of their own language and education policy. In the time since I 945 , both the North and the South have engaged heavily in the promotion of literacy. While the North banned Chinese characters outright in I 949 (though later reincorporating them into the curriculum), the characters remained a feature of South Korean writing, for which the government's support was alternately given and withdrawn from the I950s to the I 990s. Over the decades of separation, language practices in North and South Korea have diverged significantly, particularly in terms of their lexicon, the North eschewing foreign loan words and the South ambivalently embracing them [King 2007: 2 I 5-2 I 8; Schmid 2002: 258-260; $\mathrm{Yi}$ and Ramsey 20 I I : 289].

Developments in late I 9 th- and early 2oth-century Korea show how the eventual vernacularization and nationalization of language practices was a deliberate and conscious act on the part of language-reforming intellectuals both inside and outside the state. The more radical parts of the vernacular press virtually invented a new language for a new purposemass communication - and the state gradually incorporated these trends into a new mass education system. Rather than the simple diffusion of elite language among the masses, the elites themselves invented a new set of language practices, national in scope and popular in orientation, which they spread among the people. This required deliberate changes to the language itself-its written form in particular-to make it easier to learn. Moreover, the nation-state as a unit of analysis is insufficient, as Japan's imperialist behavior towards Korea demonstrates. Language change was influenced by both nationalism and imperialism. Korean language change, taking place within the context of both a nation-state as well as an empirestate, reinforces a more integrationist reading of the development of modern language practices in Asia. 


\section{Vietnam}

Vietnam is often an afterthought in the scholarly literature on East Asia, which usually focuses on China, Korea, and Japan. Indeed, Vietnam is typically classified within the separate geographical category of "Southeast" Asia. However, Vietnam, too, was a part of the elite cosmopolitanism that included China, Japan, and Korea for the better part of two thousand years prior to the 20th century [Kornicki 20 I 8: Io]. The Vietnamese were securely in the Chinese cultural orbit long after China's formal rule over the northern part of the country ended after nearly a thousand years in $939 \mathrm{CE}$. They also possessed a class of literati bureaucrats who were steeped in the use of Classical Chinese and the Confucian canon. Moreover, this class of bureaucrats was selected on the basis of the same sort of civil examinations in use in China as well as Korea, a system that was not abolished in Vietnam until i 9 I 9, more than ten years after the Chinese abandoned their examinations, and more than twenty years after the Koreans had done so as well. However, Vietnam is unique among societies that formerly used Classical Chinese as a prestige language in that it is the only one that, in the end, adopted an orthography wholly based on the Latin alphabet.

This Romanization is due in large part to the French, whose progressive conquest of Southeast Asia beginning in I859 makes them an inescapable presence in any discussion of the evolution of Vietnamese language practices. Prior to the French conquest of Vietnam, the language situation of the country was similar to that of Japan and Korea: Classical Chinese at the social apex, mastered by a privileged few in government and high culture; a vernacular literature, written by the same literate elites using an indigenous script, called chĩ nôm, adapted from Chinese characters; and numerous local forms of speech used by the rest of the people. This state of affairs was maintained and reinforced by the Nguyễn dynasty (I 802-I945), Vietnam's last, which replicated many aspects of Chinese rule. For instance, the central government, based in Huế in central Vietnam, ruled through six boards or ministries, emulating exactly the organization of the Qing imperial government. The government also selected new bureaucratic officials through a competitive civil examination system, which tested candidates on the Confucian classics in Classical Chinese, and which produced a degree hierarchy almost identical to that used in China. The Nguyễn dynasty placed Vietnam firmly back in a tributary relationship with the Qing empire; its founding emperor Gia Long (I762-I820, r. I802-I 820) even 
petitioned the Qing court for recognition of a new name for his realm, Nam Việt, and acceded to the court's modification: Việt Nam. While this is the modern name for the country, it did not come into general use until the early 2oth century. Early in the dynasty, up until I 8 I 5, nôm script was used just as frequently in palace memorials as Classical Chinese. However, the Nguyễn monarchs that succeeded Gia Long retreated into conservatism, requiring all memorials submitted to the court to be written in Classical Chinese [Kiernan 20I 7: 270-29I]. It is clear, then, that Vietnam is more than simply a national case: its evolving relations with the empire-states of China and France strongly influenced the course of its language changes.

The current appearance of written Vietnamese is perhaps what distinguishes it most from its neighbors: among the countries that formerly used Chinese writing in Asia, it is the only script written in Latin letters. This distinctive practice can be traced to the presence of Catholic missionaries, principally French Jesuits, that began proselytizing in Vietnam in the mid-I 7 th century. While he certainly was not the originator of the currently used Latin-alphabet writing system in Vietnam, the French Jesuit Alexandre de Rhodes ( I 59 I-I660) was the first to systematically codify the writing system in a dictionary published in Rome in $\mathrm{I}_{5} \mathrm{I}$. Known from the mid-I gth century onwards as quốc ngũ , this script employed the Latin alphabet with orthographic influences from French, Portuguese, and Italian, along with numerous diacritics to indicate vowel quality and tone. The term quốc ngũ itself is a curious one, given that the Chinese characters on which the term is based are the same as the ones used to represent the Chinese guóy ŭ, the Korean kuğ̌, and the Japanese kokugo, all of which mean "national language." But while the Chinese, Korean, and Japanese terms most usually refer to the spoken language (and only sometimes the written language), the Vietnamese term refers to the Romanized orthography imposed by its former French colonial rulers [DeFrancis I 977: 83-100].

Of course, in the I 9 th century, missionaries were present in many parts of Asia: many Romanized scripts were developed for various Chinese dialects, for instance, to help missionaries learn local forms of speech for the sake of proselytizing. While the intent of the Catholic missionaries in developing and using the Romanized script is not clear from the surviving documentary evidence (after $\mathrm{I}_{5} \mathrm{I}$, there were no printed texts in the script until the publication of two dictionaries by a French priest in I 838), it probably saw continued, albeit limited, use among the Catholic minority from the $\mathrm{I} 7$ th to the $\mathrm{I} 9$ th centuries [DeFrancis I 977: 6I -66 ]. The French, for their part, took up the orthography as a convenient 
means of administering their colonial holdings in Southeast Asia, for it allowed them to avoid having to deal with the language of the recalcitrant literati class-Classical Chinese-as well as the complex script based on Chinese characters that had been developed to write Vietnamese, chĩ nôm. Indeed, the French, throughout their conquest and administration of what eventually became French Indochina, sought to detach Vietnamese society from its former relations with China, considering the Chinese influence as inimical to advancing their rule, their cultural influence, and their "civilizing mission" to bring the benefits of modern technology, industry, agriculture, and medicine to the Vietnamese. In such a context, the Chinese language was seen as antithetical to modernity [DeFrancis I 977: 77, I4I-42; Kelly 2000: 96-ıо0; Marr I 98I: I 46; Taylor 20 I 3: 467].

The French conquest of Indochina proceeded in fits and starts, beginning with the seizure of Saigon in the south in I 859. By I 899, Laos, Cambodia, and the three colonial administrative units of Vietnam (Cochinchina, Annam and Tonkin) were united under French rule from Hanoi in the north. The immediate pretext for hostilities was the persecution of Catholics and Catholic missionaries, leading to abortive French attacks on Đà Nẵng in 1847 and (after Napoleon III came to power in I 852 ) in 1856 and I 858 . The more tangible reasons for the French presence in Asia were political competition with more established powers in the region (among them Britain, the Netherlands, Portugal, and Spain), economic aspirations for commodities such as cotton, sugar, silk, rice, and coffee, and markets for French manufactures [Taylor 2013: 447]. When the last attack on Đà Nẵng failed in late $\mathrm{I} 858$, the FrancoSpanish force that carried out that attack moved south and seized Saigon in I 859. The expansion of French rule into the provinces surrounding Saigon proceeded at times independently of direction from Paris, eventually resulting in the creation of the directly administered French colony of Cochinchina in the south by I 867 ['Tucker I 999: 28-30]. While the Third Republic, in the years after France's humiliating defeat by the Prussians in the war of I 870-I 87 I, hesitated in pursuing colonial expansion, French officers on the ground, hopeful for a trade route into southern China (beyond British coastal control) and mindful of competition from other European powers, attempted to gain more control over Vietnamese affairs in the north [Taylor 20 I 3:454-46 I ]. Instability in the remaining regions in the north of Vietnam under ineffectual Nguyễn emperor Tư (I829-I883, r. I 847-I883) caused the French to fear intervention by the Qing or other European powers, leading to a confrontation between Qing and French forces after the latter took Hanoi in 
I 882. The resulting Sino-French War, which lasted until I 885 , resulted in the French-induced abrogation of the tributary relationship between Vietnam and the Qing, and also in the imposition of a French protectorate over the remaining two-thirds of Vietnam: Tonkin in the north and Annam in the center, which (unlike Cochinchina in the south) were ruled indirectly through the Nguyễn court and the mandarinate selected through the examination system [Taylor I 992: 468-472, 484].

The evolution of Vietnamese language practices in the 19 th and early 2oth centuries, as a result of French conquest, proceeded almost entirely under French rule. Any assessment of the French impact and the Vietnamese response with respect to the language situation in Vietnam depends on how one interprets French administrative policy during the colonial years. Such an interpretive task, at least in the Englishlanguage literature, is complicated by painful memories of the US involvement in Vietnam, which started in the mid-I950s after the French defeat at Điện Biên Phủ in 1954 and culminated in the US withdrawal in 1972 and the conquest of South Vietnam by the North in I 976. Linguist and sinologist John DeFrancis [ [ 977: 229], strongly sympathetic to the North Vietnamese and writing in the heated aftermath of the American withdrawal, argued vehemently that the French were engaged essentially in a genocidal mission to eradicate the Vietnamese language and ultimately replace it with French. Of the debate on "association" versus "assimilation" among French colonial policymakers, in which some argued for ruling through Vietnamese institutions (association) rather than replicating French institutions (assimilation), DeFrancis took a cynical view, arguing that actual French policy hardly ever departed from assimilationist goals [DeFrancis I 977: 9I -92]. Accounts of a succeeding generation of scholars have moderated in tone and have expressed more ambivalence about the French role in Vietnam. Of the same association-assimilation debate, historian K.W. Taylor [20 I3: 467-468], who himself was deployed by the US in Vietnam during the American war, argues that, however short of their ideals they fell, the French genuinely believed in their "civilizing mission": although they recognized that the Vietnamese were already civilized, they still needed the French to bring them the benefits of modern technology and institutions. Deeply flawed as their rule was, the French, Taylor [20 I 3: 467] argues, should not be considered any more "virulent" or "corrupt" than Vietnamese regimes in generations past.

However one might characterize French motivations, two factors remain true: it was under French rule that quốc ngũ became a medium of widespread literacy, and this medium soon outran French control. The 
French themselves were responsible for spreading the quốc ngũ script beyond the narrow confines of the Catholic community, founding a network of schools across Vietnam in which Vietnamese students learned French, as well as Vietnamese written in quốc ngũ. This system of French-language schooling, known as "Franco-Vietnamese" education, began in Cochinchina in I 879 and spread north to Hanoi thereafter. By I 9 I $0,4,900$ students were enrolled in primary schools in this system in Tonkin, and by I 9 I 4, 40,000 in Cochinchina [Kiernan 20 I 7: 332]. As French and quốc ngũ became ever more important, traditional education in Classical Chinese and $n \hat{m} m$ writing steadily lost ground. The number of civil examination candidates declined, and the examinations themselves were ultimately discontinued in Tonkin in I 9 I 6 and in Annam in I 9 I 9. In 1865 , the French started the first journal to be published in quốc ngũ , the Saigon newspaper Gia Định Báo, edited by the pro-French Catholic Trương Vĩnh Ký (also known as Pétrus Ky, I 837-ı898), a polyglot genius, promoter of quốc ngũ , and author of many works in the new script. The establishment of the Gia Định Báo was followed by eight more quốc ngũ newspapers, founded between I 868 and 1907.

The Franco-Vietnamese system of education has been criticized as a deliberate strategy to keep the Vietnamese segregated from more elite schools geared towards French colonists and to preempt any notions of Vietnamese autonomy [Kelly 2000: I I 4- I I 7]. Indeed, private Vietnamese attempts at running schools were sometimes forcibly stopped-the most famous being the Tonkin Free School, founded in 1907 and shuttered by the French in I 908, in which the newest ideas in Asia were disseminated. In spite of this strategy, the last generation of Vietnamese educated in Classical Chinese and their successors, the first generation to be educated in French, were key in the development of nationalist and anticolonial thought. The dissemination of their ideas and of new ideas from abroad was greatly facilitated by growing literacy in quốc ngũu. Two early advocates of modernization, Phan Bội Châu ( I 867- I 940) and Phan Châu Trinh (I872-I926), were classically educated literati who were strongly influenced by Japanese and Chinese thinking, including the works of reformers Kang Youwei (I858-I927) and Liang Qichao (I873-1929). Both Phans advocated the abolition of the mandarinate, and both traveled to Japan. Trinh, who mastered several foreign languages as well as quốc ngũ , was impressed by Japanese mass education and influenced by the ideas of Fukuzawa Yukichi. Châu, far more antiFrench than Trinh, never mastered any languages beyond written Classical Chinese and nôm, and was a notable influence on the next generation of intellectuals, among them Hồ Chí Minh (I 890-I 969). 
This generation came of age during a time when French rule became more relaxed, starting in the I 9 I os until the outbreak of war in I 939. Governor General Albert Sarraut ( 1872 -1962), who was in office from I 9 I I to I9I 4 and then again from I9I 7 to I 9 I 9 sought a more collaborative style of French rule, and thus tried to engender enthusiasm among the Vietnamese for the regime. In I 9 I 7, the French started and funded the literary monthly Nam Phong which, until it ceased in I 934, greatly helped further the development of quốc ngũ literature. The I 920 s were crucial in the development of Vietnamese language practices, as it was then that an explosion in the amount of print media in quốc ngũ took place. One of the more notable publications during this period of literary and intellectual ferment was La cloche fêlée, a "provocative weekly newspaper" often critical of the French regime, founded in 1924 by Phan Văn Trường (I 876-I 933) and Nguyễn An Ninh (I 900-I 943), the latter of whom had studied law in France for three years [Kiernan 20 I 7 : 500; Marr I 98 I: I6I]. Overall, the I 920 s saw phenomenal growth in the number of weekly and daily periodicals being published, with sixty founded between I 923 and I 928 alone. As publishing expanded, so did the literate population; by I 939, I०\% of Vietnam's population-about I.8 million peoplecould read a newspaper [Kiernan 20 I 7: 345-48; Taylor 20 I 3: 503]. Such an estimate compares favorably with figures from Korea, where definitions of "literacy" under Japanese rule in the I 930 s required proficiency in both Japanese and Korean, something that just under $7 \%$ of the population possessed in the I930s [Pieper 2017: 496]. As Shawn McHale [2004: I I] has argued, a veritable public sphere, in which "particularistic interests contested their views," arose in Vietnam in the I 920 s.

One striking feature of the territory that now constitutes Vietnam is its relative linguistic uniformity: while there are differences in speech in different regions, the differences are relatively small and do not interfere significantly with mutual intelligibility [DeFrancis I 977: 5; Kiernan

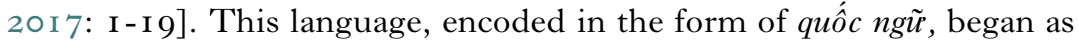
a tool for proselytizing, transitioned into a tool for the French more easily to administer their conquests, and became a weapon in the hands of the Vietnamese to spread literacy and new ideas, most notably nationalist and anticolonial ideas [DeFrancis I977: 258-59; Marr i98I: i 88]. The Vietnamese case demonstrates how the French colonial state took a writing system invented by French missionaries and deliberately spread it among its subjects. While the state intended the spread of such literacy to facilitate its rule, the writing system took on a life of its own in the hands of the Vietnamese. By the I 970s, the North Vietnamese state was actively promoting spoken Vietnamese and quốc ngũ in all areas of life, 
even where French had previously been the norm (such as in academia). One might think of quốc ngũ as even more artificial than its Asian counterparts, having been wholly invented by foreign learners of the Vietnamese language. Nevertheless, its rise, along with Vietnamese nationalism, was due in large part to the efforts of the French colonial state and then the Vietnamese state after independence. The revolution in Vietnamese language practices was not simply the diffusion of the language of one set of elites that had displaced another set. Rather, the spread of a written language that was easier to learn than the existing elite languages-Classical Chinese and Vietnamese written in nôm-was an explicitly integrationist and deliberately planned effort to incorporate the previously excluded masses into a unified linguistic field. French colonialism highlights the deliberate, conscious, and top-down nature-and also the unintended consequences - of this large-scale change in social practices.

\section{Conclusion}

The major shifts in language practices in Japan, Korea, and Vietnam were deliberate acts on the part of nation- and empire-states. The existing diffusionist understanding of the rise of national standard languages is too mechanistic and structuralist, not to mention Eurocentric. This approach conceives of a state that promotes the language of a new bourgeois elite, who supplant an aristocratic and clerical elite in possession of far more difficult language practices. Other forces, principally economic development, then facilitate the spread of this ascendant bourgeois language. Moving beyond Europe, in contrast, highlights the fact that this framework does not travel well. In this essay, I have presented a more top-down and yet egalitarian interpretation of developments that better account for three major cases beyond Europe. As we have seen in this paper, the Japanese were at the vanguard of change, while the Koreans-forcibly opened up by Japanese aggression-followed closely behind. Vietnam, on the other hand, constitutes a rather distinct case in language change: much of its linguistic culture's evolution took place under French rule between I 859 and i 945. Nonetheless, intellectuals from Vietnam were certainly in contact with their counterparts in the other countries discussed in this essay, and the influence of nationalist language ideology was strong throughout the region.

The nationalization of language in each country meant a broadening of horizons for the great masses of people who were newly empowered to gain 
literacy: mass education systems were set up by the state, and people were taught standardized languages that were simpler and more easily acquired. Rather than being merely instruments of elite domination, standard languages also facilitated the incorporation of many people previously excluded from broader political and societal discourse. At the same time, the nationalization of language also meant a narrowing of horizons-a decline in the linguistic and cultural cosmopolitanism among the region's elites. These changes were pushed forward by European incursions that threatened the independence of Japan, and also led to the end of Korean and Vietnam self-rule until the end of the Second World War.

Classical Chinese, then, was not just a language-a symbolic systembut rather an entire social phenomenon-a set of practices, institutions, and attitudes, all of which could not survive in the context of a world in which societies in Europe, organized as nation-states, sought to became empires and expand their overseas markets and ensure their commercial and political security through military threats, unequal treaties, and outright conquest. In response, societies needed military forces to protect themselves, as the Japanese were the first to realize, and modern militaries required literate soldiers drawn from a literate population. And in order to support a state-whether governing an empire or a nation-capable of providing the functions that could produce such a population, there needed to be an economy-industrialized and urbanized-that could produce the resources and technologies to support such a state and its military. In this new social reality, a language which could only be mastered by a few who were meant to rule over an illiterate many no longer had any place. In Asia in the I9th and 2oth centuries, under pressure from a European onslaught, an elite cosmopolitanism gave way to an array of popular nationalisms.

\section{BIBLIOGRAPHY}

Amsterdamska Olga, i987. Schools of Thought: The Development of Linguistics from Bopp to Saussure (Boston, D. Reidel).

Anderson Benedict R., I 99 I. Imagined Communities: Reflections on the Origin and Spread of Nationalism (New York, Verso).

Beasely W. G., I972. The Meiji Restoration (Stanford, Stanford University Press).

-, ed., I989. "The Foreign Threat and the Opening of the Ports," in The Cambridge History of Japan. Vol. 5, The Nineteenth Century (Cambridge, Cambridge University Press: 259-307)
Bourdieu Pierre, I99 I. Language and Symbolic Power, edited by J. B. Thompson (Cambridge, Harvard University Press).

Clark Paul H., 2009. The Kokugo Revolution: Education, Identity, and Language Policy in Imperial fapan (Berkeley, Center for Japanese Studies, Institute of East Asian Studies, University of California).

DeFrancis John, i 977. Colonialism and Language Policy in Viet Nam (The Hague, Mouton).

Deutsch Karl W., [1953] i 966. Nationalism and Social Communication: An Inquiry into 
the Foundations of Nationality (Cambridge, MIT Press).

Dreyer June Teufel, 20 I6. Middle Kingdom and Empire of the Rising Sun: Sino-fapanese Relations, Past and Present (New York, Oxford University Press).

Febvre Lucien and Henri-Jean Martin, 1976. The Coming of the Book: The Impact of Printing, I450-I 800 (London, NLB).

Gordin Michael D., 20I5. Scientific Babel: How Science Was Done before and after Global English (Chicago, The University of Chicago Press).

Gramsci Antonio, r 991. Selections from $\mathrm{Cul}$ tural Writings, edited by D. Forgacs and G. Nowell-Smith (Cambridge, Harvard University Press).

Green Michael J., 201 7. By More Than Providence: Grand Strategy and American Power in the Asia Pacific Since 1783 (New York, Columbia University Press).

Heinrich Patrick, 2005. "Things You Have to Leave Behind: The Demise of 'Elegant Writing' and the Rise of Genbun Itchi Style in Meiji-Period Japan," Fournal of Historical Pragmatics, 6 (I): I I 3-32.

-, 20I 2. The Making of Monolingual Japan: Language Ideology and Fapanese Modernity (Buffalo, Multilingual Matters).

HonT Istvan, 2005. Fealousy of Trade: International Competition and the Nation-State in Historical Perspective (Cambridge, The Belknap Press of Harvard University Press).

IRIYe Akira, I 989. "Japan's Drive to GreatPower Status,” in M. B. Jansen, ed., The Cambridge History of Fapan, vol. 5 (Cambridge, Cambridge University Press: 72 I-782).

KASKE Elisabeth, 2006. "Cultural Identity, Education, and Language Politics in China and Japan, I 870-1920," in D. L. Hoyt and K. Oslund, eds, The Study of Language and the Politics of Community in Global Context (Boulder, Lexington Books: 2 I 5-256).

,- 2008 . The Politics of Language in Chinese Education, I895-I9I9 (Boston, Brill).

Kelly Gail P., 2000. "Colonial Schools in Vietnam: Policy and Practice," in D. H. Kelly, ed., French colonial education: essays on Vietnam and West Africa, (New York, AMS Press: 96-I 2 I).

Kiernan Ben, 2017. Việt Nam: A History from Earliest Times to the Present (New York, Oxford University Press).

KING Ross, 2004. "Western Protestant Missionaries and the Origins of Korean
Language Modernization,” Fournal of International and Area Studies, I I (3): 7-38.

-, 2007. "Language and National Identity in the Koreas," in A. Simpson, Language and national identity in Asia (New York, Oxford University Press: 200-235).

Kornicki Peter F., 2008. "Having Difficulty with Chinese? The Rise of the Vernacular Book in Japan, Korea and Vietnam," presented at the Sandars Lecture, Cambridge, $\mathrm{UK}$.

-, 2018. Languages, Scripts, and Chinese Texts in East Asia (Oxford, Oxford University Press).

LeE Yeounsuk, I 996. The Ideology of Kokugo: Nationalizing Language in Modern Fapan (Honolulu, University of Hawai'i Press).

LEONHARDT Jürgen, 2013. Latin: Story of a World Language (Cambridge, Harvard University Press).

LiE John, 200I. Multiethnic fapan (Cambridge, Harvard University Press).

-, 2004. Modern Peoplehood (Cambridge, Harvard University Press).

MAIR Victor H., I 994. "Buddhism and the Rise of the Written Vernacular in East Asia: The Making of National Languages," The Fournal of Asian Studies 53 (3): 707-75I.

-, 2004. "Review of Hilary Chappell, Ed. Sinitic Grammar: Synchronic and Diachronic Perspectives," Sino-Platonic Papers (I 45): 8-I 4 .

MARR David G., I98I. Vietnamese Tradition on Trial, I920-I945 (Berkeley, University of California Press).

McHale Shawn Frederick, 2004. Print and Power: Confucianism, Communism, and Buddhism in the Making of Modern Vietnam (Honolulu, University of Hawaii Press).

Pieper Daniel, 20 I I. "Han'gul for the Nation, the Nation for Han'gul: The Korean Language Movement, I 894-I945," MA Thesis, Washington University in St. Louis, St. Louis. -, 20I 7. "Korean as a Transitional Literacy: Language Education, Curricularization, and the Vernacular-Cosmopolitan Interface in Early Modern Korea, I 895-I 925,” Ph.D. dissertation, University of British Columbia, Vancouver.

Platt Stephen R., 201 2. Autumn in the Heavenly Kingdom: China, the West, and the Epic Story of the Taiping Civil War (New York, Alfred A. Knopf).

Ramsey S. Robert, i 99i. "The Polysemy of the Term Kokugo,” Sino-Platonic Papers, 27: $37-47$. 


\section{JEFFREY WENG}

Schmid Andre, 2002. Korea between Empires, I895-I9I9 (New York, Columbia University Press).

Semmel Bernard, I 970. The Rise of Free Trade Imperialism: Classical Political Economy, the Empire of Free Trade and Imperialism I 750I850 (New York, Cambridge University Press).

TAylor Charles, I 992. The Ethics of Authenticity (Cambridge, Harvard University Press).

TAylor Keith Weller, 20I3. A History of the Vietnamese (Cambridge, Cambridge University Press).

Tucker Spencer, I 999. Vietnam (Lexington, University Press of Kentucky).

Twine Nanette, I978. "The Genbunitchi Movement. Its Origin, Development, and Conclusion,” Monumenta Nipponica, 33(3): 333-356.

-, I 99 I. Language and the Modern State: The Reform of Written Fapanese (New York, Routledge).
Weber Eugen. I 976. Peasants into Frenchmen: The Modernization of Rural France, I870I $9{ }^{4} 4$ (Stanford, Stanford University Press).

Weinreich Uriel, William Labov and Marvin I. Herzog, i 968. "Empirical Foundations for a Theory of Language Change," in W. P. Lehmann and Y. Malkiel, Directions for Historical Linguistics: A Symposium (Austin, University of Texas Press: 95-I 88).

Wells William Scott, 20 I I. "From Center to Periphery: The Demotion of Literary Sinitic and the Beginnings of Hanmunkwa-Korea, I876-I910," MA Thesis, University of British Columbia.

Whitney William Dwight, I 873. "On the Adoption of the English Language in Japan," in A. Mori, ed., Education in Fapan: A Series of Letters Addressed by Prominent Americans to Arinori Mori (New York, D. Appleton: I44-I 52).

Yi Ki-mun and S. Robert Ramsey, 20 I I. $A$ History of the Korean Language (New York, Cambridge University Press). 


\section{Résumé}

Les chercheurs adoptent généralement une vision "diffusionniste " de l'essor des langues nationales - l'État agit en faveur de l'adoption toujours plus large de ces langues, et d'autres forces (principalement la modernisation économique) en facilitent la diffusion. Mais une telle vision est à la fois trop mécaniste et trop eurocentrique, et l'examen d'autres cas moins connus invite à une interprétation révisée. Pendant la période de l'impérialisme occidental et la montée du nationalisme en Asie de l'Est, à la fin du XIX ${ }^{\mathrm{e}}$ et au début du Xx ${ }^{\mathrm{e}}$ siècle, un changement massif des pratiques linguistiques s'est produit entre 1870 et 1950 environ, l'hégémonie régionale passant de la Chine au Japon. Liés pendant deux millénaires par leur utilisation commune du chinois classique, les élites littéraires de Chine, de Corée, du Japon et du Vietnam se sont tous éloignés de cette lingua franca absconse pour se tourner vers la création de nouvelles langues vernaculaires nationales. Je développe dans cet article une perspective plus "intégrationniste ": la nationalisation des langues était un processus dirigé par l'État, dirigé de haut en bas, avec pour objectif de refonder la société.

Mots-clés : Langue national; Nationalisme; Japon; Corée; Vietnam; Diffusion.

\section{Zusammenfassung}

Die Forscher vertreten im Allgemeinen eine „diffusionistische“ Sichtweise der Entwicklung der Nationalsprachen - so würde der Staat die verstärkte Übernahme solcher Sprachen fördern und andere Kräfte (vor allem dank der Modernisierung der Wirtschaft) deren Verbreitung erleichtern. Diese Annahme ist jedoch sowohl zu „mechanistisch" als auch zu eurozentrisch, und die Untersuchung anderer, weniger bekannter Fälle lädt zu einer Revision ein. Während des westlichen Imperialismus und des Aufstiegs des Nationalismus in Ostasien, im späten 19. und frühen 20. Jahrhundert, kam es zwischen 1870 und 1950 zu einer massiven Veränderung der Sprachpraxis, mit einer Verlagerung der regionalen Hegemonie von China nach Japan. Die literarischen Eliten Chinas, Koreas, Japans und Vietnams, die zwei Jahrtausende lang durch ihren gemeinsamen Gebrauch des klassischen Chinesisch verbunden waren, entfernten sich von dieser abstrusen Lingua franca und schufen neue, nationale Volkssprachen. In dieser Untersuchung entwickle ich eine eher ,integrationistische“ Perspektive: Die Nationalisierung der Sprachen war ein staatlich geführter, von oben nach unten gerichteter Prozess, der auf die Neugründung der Gesellschaft abzielte.

Schlüsselwörter: Landessprache; Nationalismus; Japan; Korea; Vietnam; Verbreitung. 